\title{
Proximity-Induced Catalysis by the Protein Kinase ERK2
}

\author{
Mark A. Rainey, Kari Callaway, Richard Barnes, Brian \\ Wilson and Kevin N. Dalby*
}

College of Pharmacy, University of Texas at Austin.

\section{SUPPLEMENTARY METHODS}

\section{Expression and Purification of Proteins}

Ets $\Delta 138$ and Ets $\Delta 138-C 31$-The constructs used to express Ets $\Delta 138$ and Ets $\Delta 138-C 31$ contain DNA encoding for residues $1-138$ of murine ets-1 cDNA (with an S26A mutation introduced as a precaution against secondary phosphorylation) as well as an $N$-terminal hexa-histidine fusion tag (MGSSHHHHHHSSGLVPRGSH) that can be removed efficiently by treatment with thrombin. Ets $\Delta 138-\mathrm{C} 31$ has the following mutations; C99A, C106A, C112A. The methods of expression in, E. coli BL21 (DE3), and purification are essentially identical to those published previously. ${ }^{1}$ The concentration of Ets $\Delta 138$ and Ets $\Delta 138-\mathrm{C} 31$ were established using the extinction coefficients $\left(\mathrm{A}_{280}\right)$ of $23,231.5 \mathrm{~cm}^{-1} \mathrm{M}^{-1}$ and $22,880 \mathrm{~cm}^{-1} \mathrm{M}^{-1}$, respectively following the method of Gill and von Hippel. ${ }^{2}$

ERK2-Inactive rat ERK2 was expressed in E. coli BL21 (DE3) and purified and activated as described previously. ${ }^{3}$ 


\section{Protein Kinase assay}

Protein kinase assays were conducted as described previously ${ }^{4}$ by spotting $5 \mu \mathrm{L}$ aliquots of a $50 \mu \mathrm{L}$ reaction containing $\gamma-{ }^{32} \mathrm{P}$-ATP (ICN) onto P81 paper as described. Assays contained 1-200 nM ERK2, 25 mM HEPES pH 7.5, $50 \mathrm{mM} \mathrm{KCl,} 20 \mathrm{mM} \mathrm{MgCl}$, $0.1 \mathrm{mM}$ EDTA, $0.1 \mathrm{mM}$ EGTA, $40 \mu \mathrm{g} / \mathrm{mL}$ BSA, and $2 \mathrm{mM}$ DTT, while keeping ATP constant $(2 \mathrm{mM})$ and varying Ets $\Delta 138(6.3-200 \mu \mathrm{M})$ or while keeping Ets $\Delta 138$ constant $(200 \mu \mathrm{M})$ and varying ATP $(31.3-1000 \mu \mathrm{M})$. Initial rates were measured at each given concentration using at least 5 data points that lie in a straight line and saturation curves were fit to the Henri-Michaelis-Menten equation using Kaleidagraph (Synergy Software). The site of phosphorylation was confirmed to be Thr-38 by phosphoamino acid analysis in the case of the P39A mutant.

\section{Fluorescence Anisotropy Binding Assays}

For binding assays flurocein-labeled Ets $\Delta 138-\mathrm{C} 31$, which we term Ets $\Delta 138^{*}$ was used. The, construction, purification and characterization of this molecule is detailed in a separate manuscript (Mark A. Rainey, Kari Callaway and Kevin N. Dalby) along with a detailed description of the fluorescence-anisotropy assay. Assays were performed in 25 mM HEPES pH 7.5, 50 mM KCl, $40 \mu \mathrm{g} / \mathrm{ml}$ BSA, $0.1 \mathrm{mM}$ EDTA, $0.1 \mathrm{mM}$ EGTA, 1.3\% glycerol, and $2 \mathrm{mM}$ DTT containing ERK2 $(0-20 \mu \mathrm{M})$ and $100 \mathrm{nM}$ Ets $\Delta 138^{*}$ in a final volume of $60 \mu \mathrm{l}$. Fluorescence anisotropy measurements were made at $27^{\circ} \mathrm{C}$ using a Fluorolog Model FL3-11 fluorometer (Jobin Yvon, Edison, NJ) using three-window fluorescence grade quartz cuvettes with a $1.0 \mathrm{~cm}$ path length and $55 \mu \mathrm{L}$ aqueous volume purchased from Hellma (Plainview, NY). The program Instrument Control Center (Jobin 
Yvon, Edison, NJ) was used to collect data and to calculate the fluorescence anisotropy, $r$. Ets $\Delta 138^{*}$ was excited with polarized light at $492 \mathrm{~nm}$ and the horizontal and vertical components of the emitted light were detected at $515 \mathrm{~nm}$. Excitation and emission slit widths were set to $5 \mathrm{~nm}$ and the integration time for each reading was $300 \mathrm{msec}$. Measurements were taken every $15 \mathrm{sec}$ for a total of $3 \mathrm{~min}$ and the resulting anisotropy values were averaged. The dissociation constants were determined by fitting the average anisotropy values to equation 1 using Kaleidgraph 3.6 (Synergy software). In Equation 1, $r_{f}$ and $r_{b}$ are the anisotropies of the free and bound fluorescein-labeled protein, $R$ is the ratio of fluorescent yields of the bound form and the free form, $\left[S_{t}\right]$ and $\left[E_{t}\right]$ are the total concentration of the fluorescein-labeled protein and ERK2 respectively, and $K_{d}$ is the dissociation constant.

$$
r=\frac{\frac{\left(K_{d}+\left[S_{t}\right]+\left[E_{t}\right]\right)-\sqrt{\left(-K_{d}-\left[S_{t}\right]-\left[E_{t}\right]\right)^{2}-4\left[E_{t}\right]\left[S_{t}\right]}}{2\left[S_{t}\right]}\left(r_{b} R-r_{f}\right)+r_{f}}{1+\frac{\left(K_{d}+\left[S_{t}\right]+\left[E_{t}\right]\right)-\sqrt{\left(-K_{d}-\left[S_{t}\right]-\left[E_{t}\right]\right)^{2}-4\left[E_{t}\right]\left[S_{t}\right]}}{2\left[S_{t}\right]}(R-1)} \quad \text { equation } 1
$$

Dissociation constants for unlabeled proteins were determined from competition experiments with Ets $\Delta 138^{*}$. Assays were performed in $25 \mathrm{mM}$ HEPES pH 7.5, $50 \mathrm{mM}$ $\mathrm{KCl}, 40 \mu \mathrm{g} / \mathrm{ml} \mathrm{BSA}, 0.1 \mathrm{mM}$ EDTA, $0.1 \mathrm{mM}$ EGTA, 1.3\% glycerol, and $2 \mathrm{mM}$ DTT containing $10 \mu \mathrm{M}$ ERK2, $100 \mathrm{nM}$ Ets $\Delta 138^{*}$, and varied concentrations of competing protein in a final volume of $60 \mu \mathrm{l}$. Each reaction was equilibrated to $27^{\circ} \mathrm{C}$ before being excited with polarized light at $492 \mathrm{~nm}$. Vertical and horizontal emission was measured every $15 \mathrm{sec}$ for $3 \mathrm{~min}$ at $515 \mathrm{~nm}$. Excitation and emission slit widths were set to $5 \mathrm{~nm}$ 
and the integration time for each reading was $300 \mathrm{msec}$. The average anisotropy values were calculated and fit using equations 2-6 in Scientist (Micromath) with the values of $r_{\mathrm{f}}$ (0.11), $r_{\mathrm{b}}(0.21)$, and $K_{\mathrm{d}}$ Ets $\Delta 138^{*}(2.3 \mu \mathrm{M})$ being held constant, assuming a simple displacement model.

$$
\begin{gathered}
r=\frac{\frac{[E S]}{\left[S_{t}\right]}\left(r_{b} R-r_{f}\right)+r_{f}}{1+\frac{[E S]}{\left[S_{t}\right]}(R-1)} \\
{[E S]=\frac{\left[E_{f}\right]\left[S_{f}\right]}{K_{d}+\left[E_{f}\right]}} \\
K_{d}^{\prime}=\frac{\left[E_{f}\right]\left[B_{f}\right]}{[E B]} \\
B_{t}=B_{f}+E B \\
E_{t}=E_{f}+E B
\end{gathered}
$$$$
\text { equation } 2
$$$$
\text { equation } 3
$$$$
\text { equation } 4
$$

equation 5

equation 6

\section{References}

1. Waas, W. F.; Dalby, K. N., Purification of a model substrate for transcription factor phosphorylation by ERK2. Protein Expr Purif 2001, 23, (1), 191-7.

2. Gill, S. C.; von Hippel, P. H., Calculation of protein extinction coefficients from amino acid sequence data [published erratum appears in Anal Biochem 1990 Sep;189(2):283]. Anal Biochem 1989 Nov 1, 182, (2), 319-26.

3. Waas, W. F.; Rainey, M. A.; Szafranska, A. E.; Dalby, K. N., Two ratelimiting steps in the kinetic mechanism of the serine/threonine specific protein kinase ERK2: a case of fast phosphorylation followed by fast product release. Biochemistry 2003, 42, (42), 12273-86.

4. Waas, W. F.; Dalby, K. N., Transient protein-protein interactions and a random-ordered kinetic mechanism for the phosphorylation of a transcription factor by extracellular-regulated protein kinase 2. J Biol Chem 2002, 277, (15), 12532-40. 